\title{
APPLICATION OF A BACTERIAL EXTRACELLULAR POLYMERIC SUBSTANCE IN HEAVY METAL ADSORPTION IN A CO-CONTAMINATED AQUEOUS SYSTEM
}

\author{
Paula Salles de Oliveira Martins*; Narcisa Furtado de Almeida; Selma Gomes Ferreira Leite \\ Departamento de Engenharia Bioquímica, Centro de Tecnologia, Universidade Federal do Rio de Janeiro, Rio de Janeiro, \\ RJ, Brasil
}

Submitted: November 30, 2007; Returned to authors for corrections: March 18, 2008; Approved: November 02, 2008.

\begin{abstract}
The application of a bacterial extracellular polymeric substance (EPS) in the bioremediation of heavy metals $(\mathrm{Cd}, \mathrm{Zn}$ and $\mathrm{Cu})$ by a microbial consortium in a hydrocarbon co-contaminated aqueous system was studied. At the low concentrations used in this work ( $1.00 \mathrm{ppm}$ of each metal), it was not observed an inhibitory effect on the cellular growing. In the other hand, the application of the EPS lead to a lower concentration of the free heavy metals in solution, once a great part of them is adsorbed in the polymeric matrix $(87.12 \%$ of Cd; $19.82 \%$ of $\mathrm{Zn}$; and $37.64 \%$ of $\mathrm{Cu})$, when compared to what is adsorbed or internalized by biomass $(5.35 \%$ of $\mathrm{Cd}$; $47.35 \%$ of $\mathrm{Zn}$; and $24.93 \%$ of $\mathrm{Cu}$ ). It was noted an increase of $24 \%$ in the consumption of ethylbenzene, among the gasoline components that were quantified, in the small interval of time evaluated (30 hours). Our results suggest that, if the experiments were conducted in a larger interval of time, it would possibly be noted a higher effect in the degradation of gasoline compounds. Still, considering the low concentrations that were evaluated, it is possible that a real system could be bioremediated by natural attenuation process, demonstrated by the low effect of those levels of contaminants and co-contaminants over the naturally present microbial consortium.
\end{abstract}

Key words: EPS, co-contamination, heavy metals, natural attenuation.

\section{INTRODUCTION}

Accidental and deliberate crude oil spills have been a significant source of environmental pollution, as well as metal based and metal finishing industries. Determination and characterization of the nature of combined pollution is a problem of current interest. Waterways, rivers and ultimately the seas are contaminated with organic waste containing high concentrations of heavy metals, which are of general concern as they are persistent and able to accumulate in the ecosystem posing serious environmental and health hazard $(1,17,20)$. Still, the presence of heavy metals can inhibit the natural microbiota involved in the degradation of organic compounds and affect biodegradation rates. The level of inhibition will depend on the concentration and availability of the heavy metals and the nature of the metals, media and microbial species. Heavy metals inhibit microorganisms by blocking essential functional groups or interfering with essential metal ions incorporation of biological molecules. In some cases microorganisms are resistant to some heavy metals through different possible mechanisms (2).

Conventional processes used for removal of heavy metals from industrial wastewaters include chemical precipitation, oxireduction, filtration, electrochemical techniques and sophisticated separation processes using membranes. These processes are usually expensive, and this characteristic stimulates the use of alternative biotechnologies, due to their reduced cost and lower aggressiveness to the environment (4).

Effective strategies to enhance organic biodegradation in the presence of toxic metals include reducing the bioavailable concentration of the toxic metal and reducing interactions of the toxic metal with the cell. In their work, Sandrin et al. (17) carried out an experimental system to determine the effect of a rhamnolipid, which is an EPS produced by Pseudomonas aeruginosa 9027, on the capability of a metal-sensitive microorganism to degrade

*Corresponding Author. Mailing address: Departamento de Engenharia Bioquímica, Centro de Tecnologia, Universidade Federal do Rio de Janeiro, Rio de Janeiro, RJ, Brasil. Tel.: (21) 2562-7613. E-mail: paulamartinseq@yahoo.com.br 
organic contaminant. Their results suggested that rhamnolipid reduces $\mathrm{Cd}$ induced inhibition of naphthalene degradation through a combination of $\mathrm{Cd}$ complexation and release of lipopolysaccharide (LPS) from the cell.

Extracellular polymeric substances (EPS) play a very important role in biosorption of heavy metals, and are produced by most bacteria. EPS comprise a mixture of polysaccharides, mucopolysaccharides and proteins, which depends on the strain and its culture conditions. They contain ionizable functional groups such as carboxyl, phosphoric, amine, and hydroxyl groups, which enable EPS to sequester heavy metals. Ion exchange, complexation with functional groups of negatively charged, adsorption and precipitation are the mechanisms involved in metal biosorption onto EPS (25).

The clean-up of gasoline-contaminated groundwater continues to be a challenge. The major gasoline constituents (benzene, toluene, ethylbenzene and xylene - BTEX) are relatively soluble in water and are considered human carcinogens. Thus, the level of BTEX in water must be highly controlled and limited to low values (6). According to Van Stempvoort et al. (24), one approach that has been recently recognized for groundwater applications is natural attenuation. Natural attenuation as a management strategy for contaminated soils and sediments hinges on the notion that some transformation processes involving the in situ microbial metabolism of the target compounds are self-sustaining, appropriate with regard to type and sufficient in magnitude to control the risk associated with resident pollutants (19). Biotechnological approaches to the abatement of toxic metal and organic pollution consist of selectively using and enhancing the natural processes to treat particular wastes (22).

The aim of this work was to investigate the effect caused by the application of a bacterial EPS in bioremediation of an aqueous system co-contaminated with gasoline and heavy metals $(\mathrm{Cd}$, $\mathrm{Zn}$ and $\mathrm{Cu}$ ) by a microbial consortium.

\section{MATERIALS AND METHODS}

\section{Production, extraction and partial purification of EPS}

In order to produce EPS, it was used the Gram-positive sporeforming bacterium Paenibacillus polymyxa, isolated from fermented sausages, as described by Piuri et al. (13). The microorganism was cultivated in a solid medium of following composition (adapted from Sharma et al. (20)): sucrose $5.00 \mathrm{~g} /$ $\mathrm{L}$; yeast extract $0.15 \mathrm{~g} / \mathrm{L} ; \mathrm{KH}_{2} \mathrm{PO}_{4} 0.50 \mathrm{~g} / \mathrm{L} ;\left(\mathrm{NH}_{4}\right)_{2} \mathrm{SO}_{4} 1.0 \mathrm{~g} / \mathrm{L}$; $\mathrm{MgSO}_{4} .7 \mathrm{H}_{2} \mathrm{O} 0.41 \mathrm{~g} / \mathrm{L}$; agar $30.00 \mathrm{~g} / \mathrm{L}$; and $\mathrm{pH} 7.0$, over 2 days at $30^{\circ} \mathrm{C}$. After this time, the culture was kept under refrigeration at $10^{\circ} \mathrm{C}$. In order to activate and to obtain a pre-inoculum, subsequent cultivation took place in $400 \mathrm{~mL}$ of a medium of same composition as described above, in absence of agar, and incubated for at $30^{\circ} \mathrm{C}$ on a rotatory shaker at $150 \mathrm{rpm}$, for 24 hours. The initial cell concentration was $0.01 \mathrm{~g} / \mathrm{L}$.
The grown cells were heated until $100^{\circ} \mathrm{C}$ for 15 minutes in order to release the EPS adsorbed on cell surface. The medium was concentrated with a rotary vaporizer and further centrifuged at $3000 \mathrm{rpm}$ for 30 minutes, for removing the cells. The volume of supernatant was measured and three volumes of cold ethanol were added for EPS precipitation, and the mixture was kept under refrigeration for 24 hours. After new centrifugation, at same conditions described above, precipitated EPS was dialyzed overnight in distilled water under refrigeration. Partial purified EPS was dried in a stove at $50^{\circ} \mathrm{C}$ until constant weight.

\section{Obtainment of soil}

The soil sample used to propagate the microbial consortium was obtained in the garden of Escola de Química - UFRJ. This soil has no history of contamination with hydrocarbons and heavy metals, and because of that it would be necessary the adaptation of the microbial consortium to those conditions.

\section{Obtainment of microbial consortium}

Microbial consortium used in the experiments was obtained as described: $10 \mathrm{~g}$ of a soil sample were added to an Erlenmeyer flask with $100 \mathrm{~mL}$ of mineral medium, whose composition was $\mathrm{NaCl} 5.00 \mathrm{~g} / \mathrm{L} ; \mathrm{KNO}_{3} 3.00 \mathrm{~g} / \mathrm{L} ; \mathrm{K}_{2} \mathrm{HPO}_{4} 1.00 \mathrm{~g} / \mathrm{L} ;\left(\mathrm{NH}_{4}\right)_{2} \mathrm{SO}_{4} 1.00$ $\mathrm{g} / \mathrm{L} ; \mathrm{NH}_{4} \mathrm{H}_{2} \mathrm{PO}_{4} 1.00 \mathrm{~g} / \mathrm{L} ; \mathrm{MgSO}_{4} .7 \mathrm{H}_{2} \mathrm{O} 0.20 \mathrm{~g} / \mathrm{L}$; and $\mathrm{pH} 7.0$. Gasoline $1.00 \%(\mathrm{v} / \mathrm{v})$ was used as carbon source. The mixture was incubated at $30^{\circ} \mathrm{C}$ in a rotatory shaker at $150 \mathrm{rpm}$, for 4 days. After that, a sample of $10 \mathrm{~mL}$ was transferred to another Erlenmeyer flask, with $100 \mathrm{~mL}$ of same mineral medium and gasoline $1.00 \%(\mathrm{v} / \mathrm{v})$. This new mixture was incubated at the same conditions described above. This procedure was repeated twice, and the last flask with the microbial consortium was kept under refrigeration.

A simple macroscopic characterization of the microbial consortium colonies was carried out with plates from the last propagation step, in TSA medium (5), of following composition: gasoline $0.10 \%(\mathrm{v} / \mathrm{v}), \mathrm{NaCl} 5.00 \mathrm{~g} / \mathrm{L} ; \mathrm{K}_{2} \mathrm{HPO}_{4} 2.50 \mathrm{~g} / \mathrm{L}$, tryptone $17.00 \mathrm{~g} / \mathrm{L}$, yeast extract $2.50 \mathrm{~g} / \mathrm{L}$, agar $20.00 \mathrm{~g} / \mathrm{L}$, and $\mathrm{pH}$ 7.0. Some dilutions of culture after 72 hours were done at $30^{\circ} \mathrm{C}$, and some macroscopic characteristics of colonies were observed.

\section{Obtainment of inoculum}

In order to obtain the inoculum for the conduction of the experiments, a pre-inoculum was previously prepared in an Erlenmeyer flask containing $400 \mathrm{~mL}$ of mineral medium, amended with glucose $0.50 \mathrm{~g} / \mathrm{L}$ and gasoline $0.10 \%$ (v/v). Twenty milliliters of the system containing the microbial consortium previously obtained was added to the medium, and it was cultivated for 4 days, under $30^{\circ} \mathrm{C}$ in a rotatory shaker at $150 \mathrm{rpm}$. From this culture it was obtained a volume of inoculum to start the experiments, with initial optical density of 0.05 , measured at 440 nm, with a CamSpec spectrophotometer, model M302. 


\section{Effect of the presence of heavy metals and/or EPS in cellular growing}

Experiments were carried out in duplicate, in $200 \mathrm{~mL}$ of mineral medium, amended with gasoline $0.10 \%(\mathrm{v} / \mathrm{v})$, containing or not $1.00 \mathrm{ppm}$ of each metal $(\mathrm{Cd}, \mathrm{Zn}$ and $\mathrm{Cu})$ and/or a solution of EPS at the final concentration of $0.05 \mathrm{~g} / \mathrm{L}$. "Experiment 1 " was carried out only in presence of gasoline; "Experiment 2" was carried out in presence of gasoline and heavy metals; "Experiment 3" was carried out in presence of gasoline and EPS; and "Experiment 4" was carried out in presence of gasoline, heavy metals and EPS. A "Control 1" flask without those components was submitted to the same conditions of the experiments. Table 1 presents the compositions of the media used in different experiments. The volume of inoculum added to the media was such that the initial optical density was equal to 0.05 . The flasks were incubated in a rotatory shaker at $30^{\circ} \mathrm{C}$ and $150 \mathrm{rpm}$ for 30 hours. Samples were taken from each system after $0,6,11$ and 30 hours of cultivation.

\section{Biomass quantification}

Microbial growing was indirectly determined by intracellular protein quantification, according to Sandrin et al. (17), with the use of Lowry's method, after biomass hydrolysis with $10 \%$ (v/ v) of $\mathrm{NaOH} 1 \mathrm{M}$ at $100^{\circ} \mathrm{C}$ for 10 minutes. After reaction, absorbance was determined with an espectrophotometer CamSpec, model M302, at $660 \mathrm{~nm}$.

In order to relate samples absorbance to protein concentration, a BSA (bovine serum albumine) standard curve was built. The results of protein concentration results were the average of two values obtained for each sample, with their respective standard errors.

\section{Effect of presence of EPS in heavy metals removal}

Experiments were carried out in $200 \mathrm{~mL}$ of mineral medium, amended with gasoline $0.10 \%(\mathrm{v} / \mathrm{v}), 1.00 \mathrm{ppm}$ of each heavy metal $(\mathrm{Cd}, \mathrm{Zn}$, and $\mathrm{Cu})$, and a solution of EPS at a final concentration of $0.05 \mathrm{~g} / \mathrm{L}$. The volume of inoculum added to the media was such that the initial optical density was equal to 0.05 . The flasks were incubated in a rotatory shaker at $30^{\circ} \mathrm{C}$ at

Table 1. Compositions of media related to experiments of evaluation of cellular growing in presence or absence of heavy metals and/or EPS.

\begin{tabular}{lccc}
\hline & $\begin{array}{c}\text { Gasoline } \\
0.10 \%(\mathrm{v} / \mathrm{v})\end{array}$ & $\begin{array}{c}\mathrm{Cd}, \mathrm{Zn} \text { and } \mathrm{Cu} \\
(1 \mathrm{ppm} \text { each })\end{array}$ & $\begin{array}{c}\mathrm{EPS} \\
0.05 \mathrm{~g} / \mathrm{L}\end{array}$ \\
\hline Control 1 & no & no & no \\
Experiment 1 & yes & no & no \\
Experiment 2 & yes & yes & no \\
Experiment 3 & yes & no & yes \\
Experiment 4 & yes & yes & yes \\
\hline
\end{tabular}

$150 \mathrm{rpm}$ for 30 hours. A "Control 2" flask without inoculum was used in order to evaluate gasoline abiotic losses, as well as to evaluate the heavy metals adsorption by EPS in absence of cells. A second flask without EPS ("Experiment 5") was used in order to evaluate the heavy metals adsorption and absorption by cells in absence of EPS. "Experiment 6" involved the presence of inoculum, gasoline, heavy metals and EPS. Table 2 presents the compositions of media used in this step of the work.

Table 2. Compositions of media related to experiments of evaluation of heavy metals removal by cell and/or EPS.

\begin{tabular}{|c|c|c|c|c|}
\hline & $\begin{array}{c}\text { Inoculum } \\
0.10 \%(\mathrm{v} / \mathrm{v})\end{array}$ & $\begin{array}{c}\text { Gasoline } \\
\text { (1 ppm each) }\end{array}$ & $\begin{array}{l}\mathrm{Cd}, \mathrm{Zn} \text { and } \mathrm{Cu} \\
0.05 \mathrm{~g} / \mathrm{L}\end{array}$ & EPS \\
\hline Control 2 & no & yes & yes & yes \\
\hline Experiment 5 & yes & yes & yes & no \\
\hline Experiment 6 & yes & yes & yes & yes \\
\hline
\end{tabular}

\section{Procedures to get samples for heavy metals and hydrocarbons of gasoline quantification}

In these experiments, heavy metals were quantified in five different fractions: $\mathrm{C}_{0}, \mathrm{C}_{1}, \mathrm{C}_{2}, \mathrm{C}_{3}$ and $\mathrm{C}_{4}$.

Before addition of inoculum, a sample from medium was obtained for initial heavy metals measurements $\left(\mathrm{C}_{0}\right)$. After addition of the inoculum, experiments were conducted for 30 hours. After this time, a sample of $40 \mathrm{~mL}$ was taken and centrifuged at $3000 \mathrm{rpm}$ and 30 minutes, in order to separate the cells. These cells were kept for further analysis. Supernatant was divided in three parts: the first one was used for total soluble metals measurements after 30 hours $\left(C_{1}\right)$, the second one was used to quantify EPS adsorbed metals $\left(C_{2}\right)$ after cold ethanol precipitation, and the third one to quantify the hydrocarbons. System was filtered with a $0.22 \mathrm{~mm}$ membrane, in order to separate EPS, and the filtered was used for soluble metals measurements $\left(\mathrm{C}_{2}{ }^{\prime}\right), \mathrm{C}_{2}$ was determined by $\mathrm{C}_{1}$ minus $\mathrm{C}_{2}$ '.

Cells previously obtained were washed with $35 \mathrm{~mL}$ of a solution of EDTA $10 \mathrm{mM}$. System was centrifuged, at the same conditions described before, and supernatant was used for cells surface adsorbed metals $\left(\mathrm{C}_{3}\right)$ measurements. Cells were resuspended in $35 \mathrm{~mL}$ of distilled water, and the suspension was hydrolyzed with $10 \%(\mathrm{v} / \mathrm{v})$ of $\mathrm{NaOH} 1 \mathrm{M}$, at $100^{\circ} \mathrm{C}$ for 10 minutes. Samples were then centrifuged as already described, and supernatant was used to quantify the metals inside cells $\left(\mathrm{C}_{4}\right)$.

The removal efficiency $(h)$ was defined as:

$$
\eta=\frac{C_{0}-C_{n}}{C_{0}} \times 100
$$

where $n$ is 1,2 , or 3 . 
The metal uptake by cells or EPS $(q)$ was defined as:

$$
q=\frac{C_{0}-C_{m}}{C_{x}}
$$

where $m$ is 2 or 3 , and $C_{x}$ can be either EPS concentration or intracellular protein concentration, both in $\mathrm{g} / \mathrm{L}$.

\section{Gasoline fractions quantification}

The fractions of gasoline were quantified with a GC Trace Thermofinnigan, accopled to a Headspace Tekmar Dohrmann 7000 self-sampling. The chromatograph was equipped with a PID detector and a $30 \mathrm{~m} \times 0.53 \mathrm{~mm}$ (diameter) Megabore column. The make-up gas $\left(\mathrm{N}_{2}\right)$ flow rate was $6 \mathrm{~mL} / \mathrm{min}$, and the sheat gas $\left(\mathrm{N}_{2}\right)$ flow rate was $40 \mathrm{~mL} / \mathrm{min}$. The injection port temperature was $230^{\circ} \mathrm{C}$, and the PID detector temperature was $250^{\circ} \mathrm{C}$. The temperature program was: initial temperature $45^{\circ} \mathrm{C}$, held for 1 minute, programming rate $12^{\circ} \mathrm{C} / \mathrm{min}$ to $200^{\circ} \mathrm{C}$, held for 3 minutes. Peak areas and retention times were compared to reference standards. The injections were done in triplicate.

\section{Heavy metal measurements}

Soluble metals were quantified with an atomic absorption spectrometer Perkin Elmer, model 3100, with the following conditions: flame: air/acetylene, wave weight $228.8 \mathrm{~nm}(\mathrm{Cd})$, $213.9 \mathrm{~nm}(\mathrm{Zn})$, and $324.8 \mathrm{~nm}(\mathrm{Cu})$.

\section{RESULTS AND DISCUSSION}

\section{Effect of metals on microbial consortium growing}

Fig. 1 presents microbial consortium growing in mineral media, as described in Table 1.

As can be seen in Fig. 1, the maximum cellular growing is higher and it is reached faster in the medium containing only gasoline. The falling of the cellular concentration could be explained by the depletion of the energy source, and the posterior cellular growing is probably due to a possible consumption of the EPS or of some components released by cellular lysis in such conditions. In the medium amended with heavy metals at the concentrations used in these experiments, their presence caused a lengthening of the lag phase, probably due to an adaptation period of the microorganisms to the cocontaminated system, and the cellular growing seemed to be slower until it gets the stationary phase. This effect does not seem to greatly affect growing after ten hours of cultivation, and curves almost get the same final biomass values. Malik (11) reported that several bacterial isolated from effluents exhibited resistance to extreme conditions like $\mathrm{pH}$ peaks or high metals concentrations. According to Hassen et al. (7), at low concentrations, some metals (e.g. $\mathrm{Co}, \mathrm{Cu}, \mathrm{Zn}, \mathrm{Ni}$ ) are essential to microorganisms metabolism, since they provide vital cofactors for metallo-proteins and enzymes. In naturally polluted

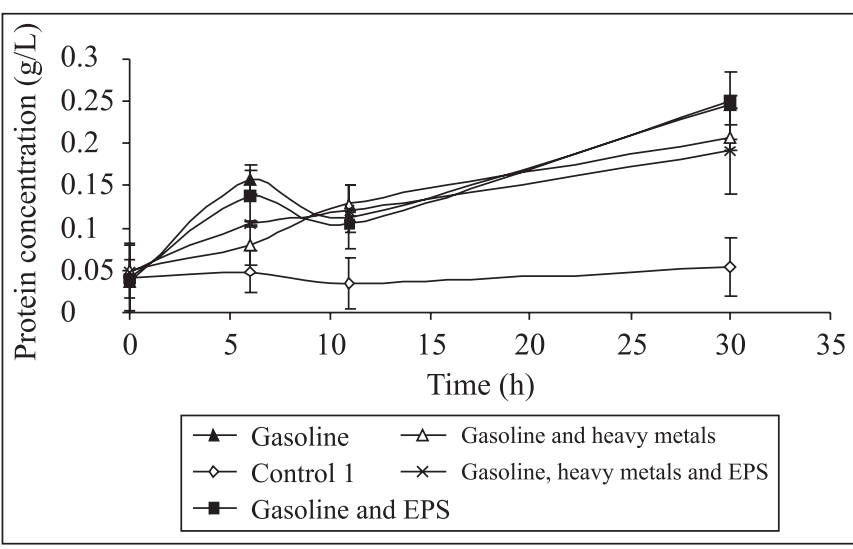

Figure 1. Microbial consortium growing in media containing or not gasoline, heavy metals and EPS.

environments, the response of microbial communities to heavy metals depends on the concentration and availability of these metals and is dependent on the actions of complex process, controlled by multiple factors such as the type of metal, the nature of medium and microbial species.

In "Experiment 3", containing gasoline and EPS, it is posible to observe that it does not occur an improvement of cellular growing, suggesting that the microorganisms do not use EPS as a carbon source. Experiments carried out with metals in presence of EPS ("Experiment 4") resulted in a similar biomass final growing, indicating that the presence of EPS does not promote any growing improvement, as confirmed by Malik (11), although it seems that some little initial increase in the curve takes place when EPS is present. According to author, multispecies consortia are considered more efficient over the monospecies culture due to greater resistance against environmental fluctuations and the metabolic relations among the member strains. Sandrin et al. (17) observed a microbial growing improvement of Bulkholderia sp. in presence of $\mathrm{Cd}$, caused by addition of a rhamnolipid produced by Pseudomonas aeruginosa strains. They confirmed that the presence of rhamnolipid reduced significantly the toxic effect caused by high concentrations of $\mathrm{Cd}$ (approximately $10000 \mathrm{ppm}$ ) and naphtalene $(26 \%(\mathrm{v} / \mathrm{v}))$ in cultivation medium.

The plattings for macroscopical characterization of microbial consortium presented two different species of bacteria (one of rosy color and other one of white color), and a specie of filamentous fungus of white color. These cultures seemed to be dominant along all experiments, once it was not observed any significant macroscopic variation of the colonies of the microbial consortium.

Results presented in Fig. 1 confirm that microbial consortium really seems to be adapted to heavy metals concentrations used in these experiments, once no negative effect was verified in 
the microbial growing, and the same final biomass concentration was virtually attained.

\section{Effect of the presence of EPS in metals removal}

Table 3 presents data concerning to metal removal efficiency (h) by adsorption by cells and EPS, and incorporated within the cells only.

Table 3. Heavy metals removal efficiency in experiments carried out in the absence and/or presence of EPS, with or without microorganisms.

\begin{tabular}{lccc}
\hline & \multicolumn{3}{c}{$\begin{array}{c}\text { Removal } \\
\text { efficiency (\%) }\end{array}$} \\
\hline Experiment in absence of EPS & $\mathrm{Cd}$ & $\mathrm{Zn}$ & $\mathrm{Cu}$ \\
Metal adsorbed on cell surface & $4.33 \%$ & $39.05 \%$ & $12.36 \%$ \\
Metal internalized by cells & $1.77 \%$ & $15.78 \%$ & $9.36 \%$ \\
Experiment in presence of EPS & $\mathrm{Cd}$ & $\mathrm{Zn}$ & $\mathrm{Cu}$ \\
Metal adsorbed on cell surface & $3.51 \%$ & $30.33 \%$ & $14.57 \%$ \\
Metal internalized by cells & $1.84 \%$ & $17.02 \%$ & $10.36 \%$ \\
Metal adsorbed on EPS & $87.12 \%$ & $19.82 \%$ & $37.64 \%$ \\
Experiment in presence of EPS & $\mathrm{Cd}$ & $\mathrm{Zn}$ & $\mathrm{Cu}$ \\
and without microorganisms & & & \\
Metal adsorbed on EPS & $98.00 \%$ & $53.25 \%$ & $51.69 \%$ \\
\hline
\end{tabular}

It is possible to note in Table 3, in relation to experiments containing EPS or not, that at the experimental conditions of cellular growing and during time cultivation, the greatest part of $\mathrm{Cd}$ and $\mathrm{Zn}$ is adsorbed on cell surface than inside cells. The amount of $\mathrm{Cd}$ that is internalized by cells is lower than $\mathrm{Zn}$ and $\mathrm{Cu}$, and can be explained by $\mathrm{Cd}$ higher toxicity to microorganisms $(9,16)$. Once $\mathrm{Zn}$ is an essential metal to cells, so as $\mathrm{Cu}$, the amount of both metals that was absorbed by cells was relatively high, and the quantity of $\mathrm{Zn}$ that is internalized is bigger probably because it is involved in many cell enzymatic activities (9).

Hassen et al. (7) presented results involving a decreasing order of toxicity in Pseudomonas aeruginosa, Pseudomonas paucimobilis and Proteus mirabilis growing: $\mathrm{Hg}>\mathrm{Co}>\mathrm{Cd}>$ $\mathrm{Cu}=\mathrm{Cr}>\mathrm{Zn}$. Castro-Silva (3) related that bacteria and fungi isolated from coal mining are resistant to high levels of $\mathrm{Cd}, \mathrm{Zn}$ and $\mathrm{Cu}$, being this resistance associated to the capacity to accumulate these elements.

The amount of cadmium adsorbed on cell surface was lower than $\mathrm{Zn}$ and $\mathrm{Cu}$, also probably due its higher toxic effect. Once $\mathrm{Zn}$ is part of several biocatalytic functions, which include about 200 enzymes, acid nucleic metabolism and cell division (9), it probably explains why this metal was adsorbed and internalized in higher quantities when compared to $\mathrm{Cu}$.
In regard to metals remotion by EPS, it is possible to verify that removal efficiency of $\mathrm{Cd}$ was higher than $\mathrm{Zn}$ and $\mathrm{Cu}$, in media containing inoculum or not. This fact could be justified by a better metal affinity to EPS than cell surface. Figs. 2 a and 2 b show metal uptake by cell surface and EPS.

Metal uptake by soluble EPS was affected by presence of cells (Fig. 2a), probably due to a protector biofilm formation around the cells, reducing the amount of free EPS available to adsorption of soluble metals. According to Priester et al. (14) and Ramey et al. (15), bacterial biofilms are tri-dimension structures that consist on extracellular polymeric substances. In this way, it is also possible to explain why metals adsorption by cells was a little higher in medium containing EPS (Fig. 2b). Once cell surface was surrounded by EPS, the quantity of heavy metals adsorbed would be higher.

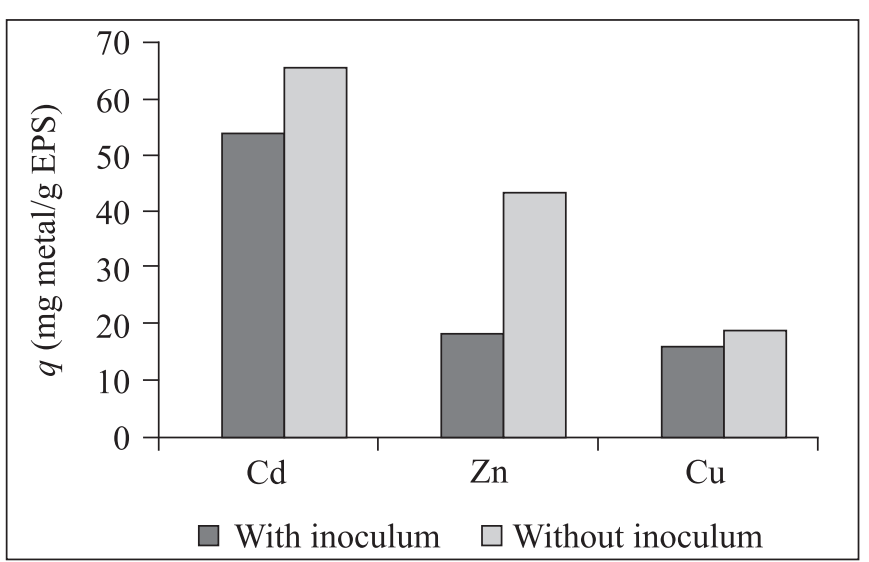

Figure 2a. Metal uptake by EPS in media containing or not microorganisms.

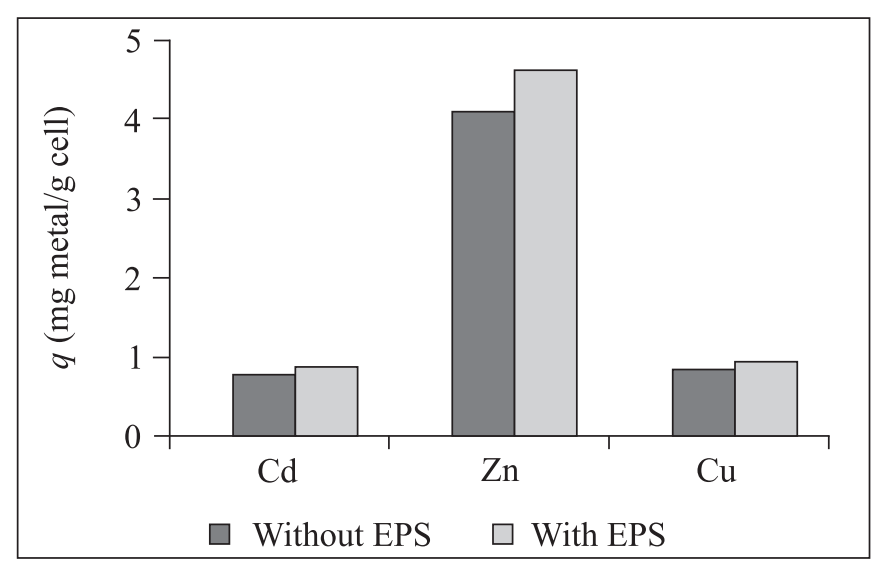

Figure 2b. Metal uptake by cell surface, in media containing or not EPS. 


\section{Gasoline hydrocarbons consumption}

In order to evaluate gasoline hydrocarbons consumption by the microbial consortium in experiments carried out in absence or presence of EPS, the fractions of benzene, toluene, ethylbenzene, meta- and para-xylene, and orto-xylene were quantified. Results are presented in Table 4.

These results were calculated deducting losses by evaporation in relation to "Control 2", carried out in absence of biomass. In regard to benzene and xylenes, it was not observed any decrease in chromatogram peaks, suggesting that these components were not consumed, the reason why these components are not presented in Table 4. The presence of EPS did not affect toluene consumption, once the results related to this hydrocarbon are statistically the same. In the other hand, it is possible to observe that, although cell growing was almost the same in media containing or not EPS, at the end of 30 hours, the presence of EPS lead to a higher consumption of ethylbenzene, which could be justified by the probable protector effect that EPS causes to cell. Merroun et al. (12) report that toxic heavy metals accumulate mainly within the EPS in experiments carried out with Myxococcus xanthus, and this fact would suggest that extracellular polymers could protect this myxobacterium in its habitats because it fixes heavy metals around the cell, avoiding their absorption. According to Tsuneda et al. (23), an EPS covering on a cell surface alters the physicochemical characteristics of the surface such as polymeric property, hydrophobicity and charge, what could favoring ionic exchange.

The heavy metals and gasoline concentrations used in this work were low; however, they were higher than the concentrations allowed by Brazilian laws to several classes of sweet and salted waters. It was possible to observe that such concentrations did not affect significantly microbial growing, suggesting that natural attenuation of the system is a very appropriate alternative in cases where contamination by heavy metals and hydrocarbons does not reach high levels. Although metal residual concentrations still are higher than the allowed for discharges by legislation, the short time in which these experiments were carried out, and the possibility of continuous cellular growing verified in Fig. 1, allow us to suppose that it would be possible to occur a higher consumption of organic

Table 4. Gasoline fractions consumption by the microbial consortium in media containing or not EPS.

\begin{tabular}{lcc}
\hline $\begin{array}{c}\text { Gasoline fractions } \\
\text { consumption in medium } \\
\text { containing heavy metals }\end{array}$ & Toluene & Ethylbenzene \\
\hline Experiment without EPS & $38.4 \%$ & $67.2 \%$ \\
Experiment with EPS & $39.2 \%$ & $91.0 \%$ \\
\hline
\end{tabular}

compounds, and the system could reach the limits of discharge for both kinds of pollutants.

According to Malik (11), in many times biosorption alone may not be sufficient for effective metal remediation. Under such situation, application of active and growing cells might be a better option due to their ability of self-replenishment, promoting a continuous metabolic uptake of metals after physical adsorption, and the potential for optimization through development of resistant species and cell surface modification.

In the other hand, there is still a possibility of production of EPS by the microbial consortium used in these experiments, what could also justify its better resistance to heavy metals. Roane et al. (16) report that strains of Pseudomonas $\mathrm{H} 1$ and Bacillus H9, isolated from soil, showed evidences of EPS production, and were resistant to high Cd concentrations.

Our results also showed that the metal uptake and removal efficiency by EPS were relatively high, and it could represent a potential application in co-contaminated systems with higher concentrations of hydrocarbons and metals, avoiding the negative effect caused by heavy metals in the biodegradation of the organic pollutant, as related by Hoffman et al. (8), Lin et al. (10) and Sandrin et al. (17).

\section{CONCLUSIONS}

In this study, the effect of application of a bacterial EPS in bioremediation of a co-contaminated system was evaluated. Our results showed that the small concentrations of heavy metals and hydrocarbons used in these experiments did not affect the microbial growing, as the EPS application did not seem to influence such growing. However, its presence in medium increased about $24 \%$ ethylbenzene consumption. EPS presented good sorption of soluble metals, demonstrating its potential application in metal detoxification, permitting an improvement of microbial activity over hydrocarbons. In the other hand, our results also indicated that a system with low concentrations of these organic and inorganic pollutants, which could be found in natural systems after a contamination with hydrocarbons, could possibly be susceptible to natural attenuation, if process is conducted in a larger period of time, without the necessity of intervention, once the microbial consortium presented good resistance and adaptation to the conditions used in these experiments.

\section{AKNOWLEDGEMENTS}

We express our gratitude to CNPq, FAPERJ and FUJB for finnancial support, and to João Alfredo Medeiros, Maria Lúcia Couto C. Pinto and Matias Ramos de Azevedo from LAAM Laboratório de Análises Ambiental e Mineral, IQ - UFRJ, for the heavy metal analysis. 


\section{RESUMO}

\section{Aplicação de uma substância polimerica extracelular bacteriana na absorção de metais pesados em um sistema aquoso co-contaminado}

A aplicação de uma substância polimérica extracelular (EPS) bacteriana na biorremediação de metais pesados $(\mathrm{Cd}, \mathrm{Zn} \mathrm{e} \mathrm{Cu})$ por um consórcio microbiano em um sistema aquoso cocontaminado com hidrocarbonetos foi estudada. Nas baixas concentrações usadas neste trabalho (1,00 ppm de cada metal), não foi observado um efeito inibitório no crescimento celular. Por outro lado, a aplicação da EPS bacteriana levou a uma menor concentração de metais livres em solução, uma vez que grande parte destes fica adsorvido na matriz polimérica $(87,12 \% \mathrm{de} C \mathrm{Cd}$; $19,82 \%$ de $\mathrm{Zn}$; e $37,64 \%$ de $\mathrm{Cu}$ ) quando comparado ao que é adsorvido ou interiorizado pela biomassa (5,35\% de Cd; $47,35 \%$ de $\mathrm{Zn} ; \mathrm{e} 24,93 \%$ de $\mathrm{Cu}$ ). No pequeno intervalo de tempo avaliado (30 horas) e na baixa concentração de gasolina utilizada $(0,1 \%$ (v/v)), foi percebido um aumento de $24 \%$ no consumo de etilbenzeno, entre os componentes da gasolina que foram quantificados. Nossos resultados sugerem que, se os experimentos fossem conduzidos em um intervalo de tempo maior, possivelmente poderia ter sido observado um maior efeito na degradação dos componentes da gasolina. Ainda, considerando as baixas concentrações avaliadas, é provável que um sistema real pudesse ser biorremediado pelo processo de atenuação natural, tendo em vista o baixo efeito desses níveis de contaminantes e co-contaminantes sobre o consórcio microbiano naturalmente presente.

Palavras-chave: EPS, co-contaminação, metais pesados, atenuação natural.

\section{REFERENCES}

1. Al-Saleh, E.S.; Obuekwe, C. (2005). Inhibition of hydrocarbon bioremediation by lead in a crude oil-contaminated soil. Int. Biodeterior. Biodegradation, 56, 1-7.

2. Amor, L.; Kennes, C.; Veiga, M.C. (2001). Kinetics of inhibition in the biodegradation of monoaromatic hydrocarbons in presence of heavy metals. Bioresour. Technol., 78, 181-185.

3. Castro-Silva, M.A.; Lima, A.O.S.; Gerchenski, A.V.; Jaques, D.B.; Rodrigues, A.L.; de Souza, P.L.; Rörig, L.R. (2003). Heavy metal resistance of microorganisms isolated from coal mining environments of Santa Catarina. Braz. J. Microbiol., 34 (Suppl.1), 45-47.

4. Da Costa, A.C.A.; Duta, F.P. (2001). Bioaccumulation of copper, zinc, cadmium and lead by Bacillus sp., Bacillus cereus, Bacillus sphaericus and Bacillus subutilis. Braz. J. Microbiol., 32, 1-5.

5. Da Cunha, C.D. (2004). Avaliação de diferentes tecnologias de biorremediação de água subterrânea contaminada com gasolina e análise molecular da comunidade bacteriana presente. Rio de Janeiro, Brasil, 176p. (D.Sc. Thesis. Escola de Química. UFRJ).

6. Da Cunha, C.D.; Leite, S.G.F. (2000). Gasoline biodegradation in different soil microcosms. Braz. J. Microbiol., 31, 45-49.

7. Hassen, A.; Saidi, N.; Cherif, M.; Boudabous, A. (1998). Effects of heavy metals on Pseudomonas aeruginosa and Bacillus thuringiensis. Bioresour. Technol., 68, 73-82.

8. Hoffman, D.R.; Okon, J.L.; Sandrin, T.R. (2005). Medium composition affects the degree and pattern of cadmium inhibition of naphthalene biodegradation. Chemosphere, 59, 919-927.

9. Hughes, M.N.; Poole, R.K. (1989). Metals and microorganisms. Springer; USA.

10. Lin, C.W.; Chen, S.Y., Cheng, Y.W. (2006). Effect of metals in biodegradation kinetics for methyl tert-butyl ether. Biochem. Eng. $J ., 32,25-32$.

11. Malik, A. (2004). Metal bioremediation through growing cells. Environ. Int., 30, 261-278.

12. Merroun, M.L.; Chekroun, K.B.; Arias, J.M.; González-Muñoz, M.T. (2003). Lanthanum fixation by Myxococcus xanthus: cellular location and extracellular polysaccharide observation. Chemosphere, 52, 113120 .

13. Piuri, M.; Sanchez-Rivas, C.; Ruzal, S.M. (1998). A novel antimicrobial activity of Paenibacillus polymyxa strain isolated from regional fermented sausages. Lett. Appl. Microbiol., 27, 9-13.

14. Priester, J.H.; Horst, A.M.; Van de Werfhorst, L.C.; Saleta, J.L.; Mertes, L.A. K.; Holden, P.A. (2007). Enhanced visualization of microbial biofilms by staining and environmental scanning electron microscopy. J. Microbiol. Methods, 68, 577-587.

15. Ramey, B.E.; Koutsoudis, M.; Von Bodmann, S.B.; Fuqua, C. (2004). Biofilm formation in plant-microbe associations. Curr. Opin. Microbioly, 7, 602-609.

16. Roane, T.M.; Josephson, K.L; Pepper, I.L. (2001). Dual bioaugmentation strategy to enhance remediation of cocontaminated soil. Appl. Environ. Microbiol., 67 (7), 3208-3215.

17. Sandrin, T.R.; Chech, A.M.; Maier, R.M. (2000). A rhamonolipid biosurfactant reduces cadmium toxicity during naphthalene biodegradation. Appl. Environ. Microbiol., 66 (10), 4585-4588.

18. Sannasi, P.; Kader, J.; Ismail, B.S.; Salmijah, S. (2006). Sorption of $\mathrm{Cr}(\mathrm{VI}), \mathrm{Cu}(\mathrm{II})$ and $\mathrm{Pb}(\mathrm{II})$ by growing and non-growing cells of a bacterial consortium. Bioresour. Technol., 97, 740-747.

19. Serrano, A. et al. (2007). Natural attenuation of diesel aliphatic hydrocarbons in contaminated agricultural soil, Environ. Pollut., doi:10.1016/j.envpol.2007.04.015

20. Sharma, P.K.; Rao, K.H.; Forssberg, K.S.E.; Natarajan, K.A. (2001). Surface chemical characterisation of Paenibacillus polymyxa before and after adaption to sulfide minerals. Int. J. Miner. Process., 62, 3-25.

21. Shen, G.; Lu, Y.; Hong, J. (2006). Combined effects of heavy metals and polycyclic aromatic hydrocarbons on urease activity in soil. Ecotoxicol. Environ. Saf., 63, 474-480.

22. Srinath, T.; Verma, T.; Ramteke, P.W.; Garg, S.K. (2002). Chromium (VI) biosorption and bioaccumulation by chromate resistant bacteria. Chemosphere, 48, 427-435.

23. Tsuneda, S.; Aikawa, H.; Hayashi, H.; Yuasa, A.; Hirata, A. (2003). Extracellular polymeric substances responsible for bacterial adhesion onto solid surface. FEMS Microbiol. Lett., 223, 287-292.

24. Van Stempvoort, D.R.; Armstrong, J.; Mayer, B. (2007). Microbial reduction of sulfate injected to gas condensate plumes in cold groundwater. J. Contam. Hydrol., 92, 184-207.

25. Zhang, D.; Wang, J.; Pan, X. (2006). Cadmium sorption by EPSs produced by anaerobic sludge under sulfate-reducing conditions. $J$. Hazard. Mater. B, 138, 589-593. 